\title{
O PRIMADO DA REALIDADE NA LEI DE INTRODUÇÃO ÀS NORMAS DO DIREITO BRASILEIRO
}

\author{
THE PRIMACY OF REALITY IN THE STATUTE OF INTRODUCTION TO THE \\ RULES OF BRAZILIAN LAW
}

Cláudio Smirne Diniz Doutor e Mestre em Direito pela Pontifícia Universidade Católica do Paraná Professor de Direito Administrativo Desembargador do Tribunal de Justiça do Estado do Paraná Curitiba / Paraná / Brasil hcdiniz@uol.com.br

Dullyan Levi Maganhati Mendes
Mestre em Direito pela Pontifícia Universidade Católica do Paraná
Advogado
Curitiba / Paraná / Brasil
rullyan@ hotmail.com

Resumo: Por intermédio da Lei n. 13.655/2018, à Lei de Introdução às Normas do Direito Brasileiro (LINDB) foram incorporados dez artigos sobre segurança jurídica e eficiência na criação e aplicação do Direito Público, sob a diretriz normativa do primado da realidade, especialmente evidenciada no caput do artigo 22. Em razão dessa mudança, à luz da Constituição da República, o presente artigo busca investigar como a nova configuração da LINDB reforça direitos, obrigações e instrumentos de modo a vincular as esferas administrativa, controladora e judicial na consecução de seu escopo. A partir do método dedutivo e de pesquisa bibliográfica e documental, atribui-se à Lei n. 13.655/2018, como resultado, o fortalecimento da articulação analítica entre os contextos fáticos e jurídicos na interpretação do Direito.

Palavras-chave: Lei de Introdução às Normas do Direito Brasileiro; aplicação do Direito; primado da realidade.

Abstract: Through Law n. 13,655/2018, Statute of Introduction to the Rules of Brazilian Law (LINDB) ten articles on legal certainty and efficiency in the creation and application of Public Law were incorporated, under the normative guideline of the primacy of reality, especially evidenced in the caput of article 22. Due to this change, in the light of the Constitution of the Republic, this article seeks to investigate how the new configuration of LINDB reinforces rights, obligations and instruments in order to bind the administrative, controlling and judicial spheres in the achievement of its targets. From the deductive method and bibliographic and documentary research, it can be attributed to Law n. 13,655/2018, as a result, the strengthening of the analytical articulation between factual and legal contexts in the interpretation of Law.

Keywords: Statute of Introduction to the Rules of Brazilian Law; Law application; primacy of reality. 
DINIZ, Cláudio Smirne; MENDES, Rullyan Levi Maganhati. O primado da realidade na lei de introdução às normas do direito brasileiro

Para citar este artigo (ABNT NBR 6023:2018)

DINIZ, Cláudio Smirne; MENDES, Rullyan Levi Maganhati. O primado da realidade na lei de introdução às normas do direito brasileiro. Revista Thesis Juris - RTJ, São Paulo, v. 10, n. 2, p. 222-252, jul./dez. 2021. http://doi.org/10.5585/rtj.v10i2.17636.

\section{Considerações iniciais}

De conformação supralegal e transversal, a Lei de Introdução às Normas do Direito Brasileiro (LINDB) constitui-se em um guia interpretativo do ordenamento jurídico endereçado àqueles que detêm a competência de aplicação das leis, tanto na esfera administrativa quanto na judicial. Instituída pelo Decreto-Lei n. 4.657/1942, no contexto da ditadura varguista, foi originalmente denominada como Lei de Introdução ao Código Civil Brasileiro (LICC), refletindo a matriz privatista e oitocentista do Direito naquela quadra. Com sua racionalidade sistematicamente superada com o passar das décadas, sobretudo com o processo de redemocratização do país e de constitucionalização do Direito, à LICC foi atribuído o atual nomen juris pela Lei n. 12.376/2010, sem que houvesse mudança de seu conteúdo.

Nesse percurso, após reformas pontuais, a LINDB foi substancialmente alterada com o advento da Lei n. 13.655/2018, que nela acresceu dez artigos sobre segurança jurídica e eficiência na criação e aplicação do Direito Público, informados por uma orientação pragmática sintetizada pela doutrina na expressão primado da realidade.

Sob o viés realista, a publicização da LINDB reúne preceitos que buscam aprimorar e fortalecer a qualidade das decisões administrativas, controladoras e judiciais. Para tanto, elege parâmetros hermenêuticos de conteúdo aberto, como a consideração de obstáculos e dificuldades reais do gestor público, que, a depender do manejo efetuado, serão capazes de subverter a própria razão de ser do diploma.

Nesse sentido, tomada a modificação legislativa como problema de pesquisa, importa investigar como a diretriz do primado da realidade contida na Lei n. 13.655/2018 estabelece ou reforça direitos, deveres e instrumentos com o propósito de enforcement à segurança jurídica e incremento da eficiência da Administração Pública e dos órgãos de controle.

Com esse objetivo, utilizando-se de metodologia dedutiva de abordagem científica e de técnicas de pesquisa bibliográfica e documental, este artigo foi estruturado em três seções. Busca-se, na primeira, descrever brevemente o surgimento e trâmite legislativo da Lei n. 13.655/2018, com menção ao debate público, polarizado, condicionante de sua aprovação. Na seguinte, os apontamentos incidem sobre o ponto focal de cada dispositivo agregado à LINDB, 
de acordo com o perfil prático e reiterado do texto e interpretação conforme a Constituição da República, cuja proposta agrupa os artigos em normas gerais para o Direito, normas gerais de Direito Administrativo e normas específicas de Direito Administrativo. Finalmente, analisa-se de modo particular o caput do artigo 22, empregado como metonímia da Lei n. 13.655/2018, sob dúplice enfoque: a interpretação do primado da realidade na Administração Pública (e seu controle) diante do cenário de incerteza gerado pela abundância de princípios jurídicos e diante dos diversos contextos fáticos e materiais de realização do Direito.

\section{A emergência da Lei n. 13.655/2018 e a publicização da Lei de Introdução às Normas do Direito Brasileiro}

A Lei n. 13.655/2018 possui "DNA acadêmico" (DUQUE; RAMOS, 2019, p. 24), proveniente de uma proposta de projeto legislativo, divulgada cinco anos antes, em obra desenvolvida por Carlos Ari Sundfeld e Floriano de Azevedo Marques Neto, advogados e professores de Direito Administrativo (SUNDFELD; MARQUES NETO, 2013, p. 277-285).

Em junho de 2015, encampada pelo Senador Antonio Augusto Junho Anastasia, transformou-se no Projeto de Lei do Senado (PLS) n. 349, dando início à fase de apreciação legislativa. Durante o curso na Comissão de Constituição, Justiça e Cidadania (CCJ) daquela Casa, uma única audiência pública acerca do PLS foi realizada ${ }^{1}$, quinze emendas foram apresentadas e acolhidas - como a reordenação sequencial dos dispositivos por conexão temática e a inclusão do artigo 30, "para concretizar o princípio da segurança jurídica" (BRASIL, 2017a, p. 15) -, e, ao final, a Relatora, Senadora Simone Nassar Tebet, votou favoravelmente à aprovação do Projeto. Sem oposição de recurso pelo Plenário, o texto anuído do PLS n. 349/2015 foi remetido à Câmara dos Deputados em abril de 2017.

Recebido na Casa Revisora, foi distribuído como Projeto de Lei (PL) n. 7.448/2017 à Comissão de Constituição e Justiça e Cidadania, sendo, seis meses depois, aprovado pelo Relator, o Deputado Federal Paulo Abi-Ackel. Dessa aprovação sem emendas, houve recurso da Deputada Federal Érika Jucá Kokay, adiante retirado por acordo de líderes. Segundo o recurso, os dispositivos apontavam "inexoravelmente para um sentido inverso ao proposto" e "poderiam ter sido aperfeiçoados acaso o debate público no âmbito do Parlamento [...] conseguisse envolver, de forma plural, os potencialmente atingidos" (BRASIL, 2017b, p. 2).

\footnotetext{
${ }^{1}$ De acordo com o sítio eletrônico do Senado Federal, a audiência pública destinada à instrução da matéria ocorreu em 19 de novembro de 2015, na 39 Reunião Extraordinária, conforme Requerimento n. 35, de 2015-CCJ, de iniciativa da Senadora Simone Tebet. Disponível em: https://www25.senado.leg.br/web/atividade/materias//materia/121664. Acesso em: 25 out. 2021.
} 
Embora "formalmente legal, mas democraticamente reprovável" (VITORELLI, 2020, p. 81), visto que atestada "a mais absoluta ausência de discussão da matéria com os órgãos de controle" (OLIVEIRA, 2018b, p. 25-26), o PL n. 7.448/2017 foi encaminhado ao Presidente da República em 5 de abril de 2018, para sanção e promulgação ou veto. No curto período em que esteve sob análise presidencial - não mais que vinte dias -, gerou consistente e aprofundada argumentação entre advogados e acadêmicos de Direito Público, de um lado, e os órgãos de controle e associações de classe, de outro, sobre as inovações oferecidas.

Em entendimento contrário ao PL, reputado como "uma inequívoca tentativa de fragilizar o controle sobre a atuação dos agentes públicos" (DUQUE; RAMOS, 2019, p. 25), além de exprimir uma compilação de inconstitucionalidades e ilegalidades, destacaram-se as manifestações do Ministério Público Federal (MPF), da Associação Nacional dos Magistrados da Justiça do Trabalho (ANAMATRA) e do Tribunal de Contas da União (TCU), este, em especial, merecedor de réplica por parte dos mentores acadêmicos do projeto, seguida de nova refutação pela Corte de Contas $^{2}$.

Como saldo desse antagonismo, credita-se aos "intensos debates, seguramente dos mais profícuos no ambiente juspublicista dos últimos anos" (HAEBERLIN, 2019, p. 80), o veto a alguns dos pontos controvertidos da proposta.

Sancionada e promulgada a Lei n. 13.655 em 25 de abril de 2018, os novos dispositivos da LINDB, na tentativa de objetivação, foram regulamentados pelo Decreto n. 9.830, em junho de 2019.

Os artigos acrescidos - do 20 ao 30, à exceção do 25, vetado - são relativamente sucintos, ao estilo da LINDB, e, em rigor, não constituem uma novidade. Particularmente e em conjunto, partindo da premissa de instabilidade decisória na seara pública - sobretudo no controle da Administração Pública -, "trazem a realidade para dentro dos jogos de aplicação da lei" (SUNDFELD, 2019, p. 11) com o fulcro de "neutralizar, de algum modo, importantes fatores de distorção da atividade jurídico-decisória pública, afetando sua eficiência e segurança jurídica" (SUNDFELD; MARQUES NETO, 2013, p. 278).

Dado o status normativo e topográfico da LINDB, entendeu-se ser o diploma apropriado para veiculação da Lei n. 13.655/2018, de forma a obrigar autoridades federais, estaduais, distritais e municipais de todos os órgãos e Poderes.

\footnotetext{
${ }^{2}$ Entre outras manifestações públicas, opuseram-se ao PL n. 7.448/2017 a Procuradoria-Geral da Fazenda Nacional, o Conselho Nacional dos Procuradores-Gerais de Contas, a Associação Nacional do Ministério Público de Contas, a Associação dos Membros dos Tribunais de Contas do Brasil, a Associação Nacional dos Ministros e Conselheiros-Substitutos dos Tribunais de Contas e o Colégio Nacional de Presidentes de Tribunais de Contas.
} 


\section{A Lei n. 13.655/2018: interpretação conforme e hermenêutica do reforço}

Imbuída do Direito desta época - essencialmente dinâmico, mutável, espiralado, plurissubjetivo e diacrônico (MARQUES NETO; MOREIRA, 2015, p. 11) -, a publicação da Lei n. 13.655/2018, designada como Lei da Segurança Jurídica, representa uma reação à considerável fluidez de motivação das escolhas públicas e "resposta [...] a um ambiente em que o sincretismo metodológico muitas vezes contribui para a inação administrativa" (GUIMARÃES, 2019, p. 341). Nesse lanço, adotou o "paradigma de que as autoridades não podem tomar decisões desconectadas do mundo real; de que elas têm o dever de medir consequências, de considerar alternativas, [...] de pesar os obstáculos e circunstâncias da vida prática" (SUNDFELD; MARQUES NETO, 2013, p. 279).

Em razão do vasto escopo, objetiva fomentar maior coerência do ordenamento, "unificando conceitos desde o Direito Penal até o Direito Administrativo (sancionador ou não), passando até pelo Direito Processual (Penal, Civil, Trabalhista e Eleitoral)" (BRASIL, 2017a, p. 5). Contudo, a literatura e a jurisprudência (esta, ainda incipiente) têm questionado a abrangência pretendida e ofertado limitações à incidência "ampla, geral, irrestrita e indiscriminada" dos novos dispositivos, seja na análise singular de artigo e ramo jurídico - caso do artigo 24 aplicado ao Direito Tributário -, seja na aplicação em áreas específicas - como a do Direito Penal e Processual Penal -, "sobretudo levando em conta aspectos peculiares da dicção [...] que visivelmente fecham o foco para aspectos bastante limitados e circunscritos", como os de Direito Administrativo (ANDRADE, 2019, p. 125-126).

Nesse sentido, dentre as variadas classificações disponíveis, entende-se apropriada a categorização da LINDB a partir da técnica de interpretação conforme a Constituição ${ }^{3}$, como propõe o advogado e pesquisador Fábio Martins de Andrade em obra sobre o tema. A aplicação da LINDB, defende o autor, pode ser dividida em normas gerais para o Direito, normas gerais de Direito Administrativo e normas específicas de Direito Administrativo (ANDRADE, 2019, p. 127).

Com esteio nessa sistematização, apresenta-se nas subseções seguintes o núcleo dos artigos acrescentados à LINDB, no intuito de obter um panorama de encadeamento e interdependência normativa, à luz do primado da realidade. Ainda, no arremate da seção,

\footnotetext{
${ }^{3}$ A saber: "Essa técnica se resume em recomendar que os aplicadores da Constituição, deparando-se com normas infraconstitucionais de múltiplos significados, escolha o sentido que as torne constitucionais [...]. Isso permite a valorização do trabalho legislativo, preservando a lei no ordenamento, e evitando conflitos em âmbito da separação de Poderes [...]” (NISHIYAMA; PINHEIRO; LAZARI, 2018, p. 161, grifo do autor).
} 
comenta-se acerca da principal característica hermenêutica trazida pela Lei n. 13.655/2018, globalmente considerada.

\subsection{As normas gerais para o Direito}

No primeiro grupo, com atributo normativo adaptável e destinatários genéricos, reúnemse os artigos 20, caput, 23, 29 e 30 da LINDB, que tratam de aspectos afeitos à interpretação e aplicação do Direito Público. Esses dispositivos "claramente têm potencial para se espraiarem sobre os mais variados ramos do Direito, com aplicação geral” (ANDRADE, 2019, p. 127).

O artigo 20, caput, inaugura a tônica de pragmatismo, com distintas gradações, aplicada aos novos dispositivos da LINDB (DIDIER; OLIVEIRA, 2019, p. 150). Determina que, "nas esferas administrativa, controladora e judicial, não se decidirá com base em valores jurídicos abstratos sem que sejam consideradas as consequências práticas da decisão" (BRASIL, 2018) 4 . Enfrenta e relaciona, desse modo, duas questões: o "uso subjetivista, decisionista (ou voluntarista) e irresponsável dos valores jurídicos abstratos" (MAFFINI, 2019a, p. 49) - com destaque para os princípios normativos e seu emprego neoconstitucional - e o consequencialismo jurídico, isto é, a consideração de causas e efeitos de determinada opção interpretativa com fundamento na experiência contextualizada.

De árdua definição, pode-se afirmar que valores jurídicos abstratos são aqueles "cujos termos são ambíguos ou imprecisos - especialmente imprecisos -, razão pela qual necessitam ser completados por quem os aplique" (GRAU, 2003, p. 200). No artigo $3^{\circ}, \S 1^{\circ}$, do Decreto $n$. 9.830/2019, regulamentador da LINDB, são conceituados como "previstos em normas jurídicas com alto grau de indeterminação e abstração" (BRASIL, 2019), em texto apontado como de “reprovável circularidade de raciocínio" (VITORELLI, 2020, p. 85).

O caput do artigo 20 veda decisões baseadas em valores abstratos sem a devida análise de consequencialidade, de forma que, se contemplados, devem ser atrelados à situação e repercussão - entre as partes e coletivamente - de cada caso concreto, assegurando "maior

\footnotetext{
${ }^{4}$ Em detalhamento: "Esfera administrativa mostra-se de sentido largo, para abranger todos os agentes que decidem nos órgãos e entes da Administração direta e indireta da União, Estados, Distrito Federal e Municípios. [...] Esfera controladora diz respeito aos órgãos ou entes que exercem controle interno e externo sobre atuações da Administração Pública direta e indireta. Podem ser exemplificados, no controle interno, os órgãos contábeis e financeiros do próprio órgão ou ente público, as controladorias, as ouvidorias, as corregedorias; no controle externo, os Tribunais de Contas, o Ministério Público. [...] Esfera judicial abarca os juízes e os membros dos tribunais do Poder Judiciário. Embora o Poder Judiciário se enquadre na condição de 'esfera controladora' da Administração Pública, o dispositivo indicou explicitamente tal esfera, talvez por clareza” (MEDAUAR, 2018, p. 64 , grifo do autor).
} 
controle intersubjetivo da argumentação" e menor margem de insegurança jurídica (DUQUE; RAMOS, 2019, p. 30).

Nesse entendimento, “a previsão dos efeitos práticos da decisão é indispensável para determinar a compatibilidade da escolha realizada com o valor abstrato invocado" (JUSTEN FILHO, 2018, p. 29), ou seja, as consequências práticas passam a ser "decorrência - lógica, jurídica, ou fática - da decisão" (MENDONÇA, 2018, p. 50). Nessa toada, entre outras correspondências, o artigo 20 da LINDB "funciona como [...] um parágrafo" do artigo 489 do Código de Processo Civil (CPC), "porque estabelece mais uma situação em que a fundamentação pode ser considerada deficiente" (DIDIER; OLIVEIRA, 2019, p. 152).

$\mathrm{Na}$ continuidade dos dispositivos da Lei n. 13.655/2018 com desígnio de norma geral para o Direito, o artigo 23 atribui aos particulares o direito à transição adequada quando do surgimento de novas situações jurídicas passivas ${ }^{5}$. Nessa perspectiva, assegura que o Direito corresponda ao dinamismo da realidade mediante a modulação dos efeitos da mudança interpretativa, expediente previsto no artigo 146 do Código Tributário Nacional, por exemplo. Designa, para tanto, "um regime jurídico de passagem, de duração temporária" (ANDRADE, 2019, p. 213), afastado da lógica binária dos efeitos ex tunc e ex nunc (SILVEIRA; SILVA, 2018, p. 245), e fundado na proteção da confiança legítima e na segurança jurídica em sentido subjetivo. Permite, dessa forma, que o percurso para a nova situação jurídica aconteça de maneira previsível a fim de que, nesse intervalo, ocorra a adequação fático-jurídica à norma reinterpretada ${ }^{6}$.

Na sequência, o artigo 29 da LINDB, também de incidência ampla e geral, determina que "[...] a edição de atos normativos por autoridade administrativa, salvo os de mera organização interna, poderá ser precedida de consulta pública para manifestação de interessados, preferencialmente por meio eletrônico, a qual será considerada na decisão" (BRASIL, 2018) $)^{7-8}$.

De modo a substanciar a dialogicidade entre o Poder Público e a sociedade no agir administrativo - à semelhança dos artigos 31 a 34 da Lei n. 9.784/1999 (do processo

\footnotetext{
${ }^{5}$ É a dicção do dispositivo: "Art. 23. A decisão administrativa, controladora ou judicial que estabelecer interpretação ou orientação nova sobre norma de conteúdo indeterminado, impondo novo dever ou novo condicionamento de direito, deverá prever regime de transição quando indispensável para que o novo dever ou condicionamento de direito seja cumprido de modo proporcional, equânime e eficiente e sem prejuízo aos interesses gerais" (BRASIL, 2018).

${ }^{6}$ Cabe observar que o regime de transição é considerado apenas em relação às normas de conteúdo indeterminado, como se as demais não se sujeitassem a variações interpretativas (DINIZ; DINIZ, 2018, p. 286).

${ }^{7}$ Em complemento: “Art. $29, \S 1^{\circ}$. A convocação conterá a minuta do ato administrativo e fixará o prazo e demais condições da consulta pública, observadas as normas legais e regulamentares específicas, se houver" (BRASIL, 2018).

${ }^{8}$ A Lei n. 13.655/2018 definiu o prazo de 180 dias de vacatio legis para o artigo 29.
} 
administrativo federal) e do artigo 10, inciso VI, da Lei n. 11.079/2004 (da licitação e contratação de parceria público-privada) -, o artigo 29 da LINDB afirma o "princípio democrático, de matriz constitucional, tendente à descentralização das decisões de diferentes searas, intensificando-se o processo de participação" (DINIZ; DINIZ, 2018, p. 292). Gera-se, nesse aspecto, "um grau maior de legitimação e justeza da norma administrativa" (RODRIGUES, 2019, p. 184).

A doutrina diverge acerca da obrigatoriedade da prévia consulta pública ${ }^{9}$ definida pelo dispositivo: de um lado, entende-se que o texto legal atribuiu competência discricionária à autoridade, cujo balizamento é feito por critérios de conveniência e oportunidade, ou seja, que permitiu-se ao Poder Público decidir se realiza ou não a consulta pública - a ponto de, no extremo, "decidir em cem por cento dos casos pela não realização" (RODRIGUES, 2019, p. $185)$-; ao revés, defende-se a existência de um poder-dever incondicionado de realização, compreendido como "condição de validade de ato administrativo normativo" (MONTEIRO, 2018, p. 239).

Interessa registrar que o artigo 18 do Decreto n. 9.830/2019 repete a redação do artigo 29 da LINDB, suprimindo, contudo, a determinação de que a consulta pública será considerada na decisão, o que pode representar o enfraquecimento ou emprego menos efetivo do instrumental de participação ${ }^{10}$.

Em arremate, o artigo 30 da LINDB, adicionado durante o trâmite legislativo no Senado Federal, determina que "as autoridades públicas devem atuar para aumentar a segurança jurídica na aplicação das normas, inclusive por meio de regulamentos, súmulas administrativas e respostas a consultas". Esses instrumentos, consoante o parágrafo único do dispositivo, "terão caráter vinculante em relação ao órgão ou entidade a que se destinam, até ulterior revisão" (BRASIL, 2018).

Embora pareça despiciendo e intuitivo, já que a segurança jurídica é norma derivativa da noção de Estado de Direito (ANDRADE, 2019, p. 313), o diferencial trazido pelo artigo 30 diz respeito ao caráter vinculante dos instrumentos exemplificativamente elencados. Nesse sentido, é "a peça que assegura [...] coerência e sustentabilidade [...] ao sistema instalado pela Lei n. 13.655/2018, ao determinar que a aplicação dos dispositivos [...] seja respeitada

\footnotetext{
${ }^{9}$ Explica-se que "a consulta pública é 'irmã-gêmea' da audiência pública. A audiência pública é ato presencial, baseada em debates e discussões orais entre agentes do Poder Público e [...] sociedade civil [...]. Já a consulta pública é ato não-presencial. Trata-se de um procedimento de comunicação indireta e não pessoal entre o Poder Público e a sociedade civil" (RODRIGUES, 2019, p. 181-182).

${ }^{10}$ É de se mencionar que "o Poder Público não é obrigado a acatar o que foi decidido na audiência/consulta pública, mas sua recusa deve vir sempre acompanhada de motivação, isto é, da demonstração dos motivos pelos quais os pleitos não foram atendidos" (LEVIN, 2018, p. 466-467).
} 
horizontal e verticalmente" (MOREIRA; PEREIRA, 2018, p. 270). Junto a isso, por força da LINDB, "agora é do estado, e não dos destinatários, o ônus de obter segurança e certeza quanto ao conteúdo e efeitos das leis no campo público" (SUNDFELD, 2019, p. 12).

\subsection{As normas gerais de Direito Administrativo}

O segundo grupo é composto pelos artigos 20, parágrafo único, 21, 22, 24 e 28 da LINDB, dispositivos que evidenciam a preocupação com a validade ou invalidação de ato, contrato, ajuste, processo ou norma administrativa e, também, com a figura do gestor público. Pela própria redação, limitam-se a incidir no Direito Administrativo, "embora com trânsito amplo, geral e irrestrito nos seus mais diversos subsistemas de maneira indistinta”, como o regulatório, sancionatório e do ambiente (ANDRADE, 2019, p. 128).

De acordo com o parágrafo único do artigo 20, “a motivação demonstrará a necessidade e a adequação da medida imposta ou da invalidação de ato, contrato, ajuste, processo ou norma administrativa, inclusive em face das possíveis alternativas" (BRASIL, 2018). Adensando o conteúdo do artigo 93, inciso IX, da Constituição da República ${ }^{11}$ e em consonância com o CPC (aplicável, aliás, supletiva e subsidiariamente aos processos decisórios administrativos), o dispositivo qualifica a necessidade de motivação da decisão, trazendo "um reforço no ônus argumentativo, seja do administrador público, seja do controlador" (DUQUE; RAMOS, 2019, p. 30, grifo do autor). Seguindo a linha de modulações consequenciais, prevê a consideração das possíveis alternativas entre as informadas para a Administração Pública ou sobre as quais se tenha razoável dever de conhecimento.

Na mesma dimensão pragmática do artigo 20, o artigo 21 da LINDB reitera a observância do consequencialismo jurídico e administrativo e, assim o fazendo, "exige que esse enfrentamento dos desdobramentos reais ocorra não apenas para definir se um ato é inválido ou não, mas também para explicitar quais serão as consequências concretas da invalidação do ato administrativo" (OLIVEIRA, 2018a, p. 23) ${ }^{12}$. Nesse aspecto, as “consequências deverão estar motivadas com embasamento coerente, apresentando dados concretos, embasados

\footnotetext{
${ }^{11}$ In verbis: “Art. 93, IX. Todos os julgamentos dos órgãos do Poder Judiciário serão públicos, e fundamentadas todas as decisões, sob pena de nulidade [...]" (BRASIL, 1988).

12 É o texto normativo: “Art. 21. A decisão que, nas esferas administrativa, controladora ou judicial, decretar a invalidação de ato, contrato, ajuste, processo ou norma administrativa deverá indicar de modo expresso suas consequências jurídicas e administrativas. Parágrafo único. A decisão a que se refere o caput deste artigo deverá, quando for o caso, indicar as condições para que a regularização ocorra de modo proporcional e equânime e sem prejuízo aos interesses gerais, não se podendo impor aos sujeitos atingidos ônus ou perdas que, em função das peculiaridades do caso, sejam anormais ou excessivos" (BRASIL, 2018, grifo do autor).
} 
logicamente, lastreadas em indicadores, com referências de prognósticos, [...] contornando o receio do 'exercício de futurologia"' (CUNDA, 2019, p. 71, grifo do autor) ${ }^{13}$.

Por sua vez, o artigo 22, caput, da LINDB determina que, "na interpretação de normas de gestão pública, serão considerados os obstáculos e as dificuldades reais do gestor e as exigências das políticas públicas a seu cargo, sem prejuízo dos direitos dos administrados" (BRASIL, 2018). Dessa forma, “combate o idealismo dominante no Direito brasileiro e exige do intérprete maior atenção às circunstâncias fáticas e jurídicas que impactam a decisão administrativa e podem limitá-la" (JORDÃO, 2018, p. 63). Evidencia, em síntese, o mandamento de "consideração da realidade" (HAEBERLIN, 2019, p. 85, grifo do autor), interesse precípuo desta pesquisa, a ser analisado com maior vagar na seção seguinte. Nessa senda, os parágrafos do artigo 22, guiados pela dosimetria oferecida pelo artigo 128 da Lei n. 8.112/1990 (do regime jurídico dos servidores públicos civis federais), priorizam a realidade quando da aplicação de sanções aos agentes, sopesando a natureza e gravidade da infração, os danos dela decorrentes, elementos atenuantes, agravantes e antecedentes.

Adiante, na consagração do brocardo tempus regit actum, o artigo 24 consolida as orientações gerais da época na validade decisória, ou seja, aborda a irretroatividade de nova interpretação e, com isso, mitiga a lógica de que inexiste direito adquirido a regime jurídico no Direito brasileiro (MAFFINI, 2019b, p. 125) ${ }^{14}$. Prescreve, como se um continuum do artigo $2^{\circ}$, parágrafo único, da Lei n. 9.784/1999, anteriormente referida, o "direito à previsibilidade das mudanças interpretativas das autoridades decisórias e controladoras estatais" (MARQUES JUNIOR, 2018, p. 295, grifo do autor). A aplicação das orientações gerais, expressão definida no parágrafo único do artigo, dependerá de um "ônus demonstrativo" no exame peculiar de cada caso (CÂMARA, 2018, p. 133) ${ }^{15}$.

\footnotetext{
${ }^{13}$ Visando balizar a prognose jurídica, o artigo $4^{\circ}, \S 1^{\circ}$, do Decreto n. 9.830/2019 estipula que "a consideração das consequências jurídicas e administrativas é limitada aos fatos e fundamentos de mérito e jurídicos que se espera do decisor no exercício diligente de sua atuação" (BRASIL, 2019).

${ }^{14}$ Determina o artigo 24: “A revisão, nas esferas administrativa, controladora ou judicial, quanto à validade de ato, contrato, ajuste, processo ou norma administrativa cuja produção já se houver completado levará em conta as orientações gerais da época, sendo vedado que, com base em mudança posterior de orientação geral, se declarem inválidas situações plenamente constituídas. Parágrafo único. Consideram-se orientações gerais as interpretações e especificações contidas em atos públicos de caráter geral ou em jurisprudência judicial ou administrativa majoritária, e ainda as adotadas por prática administrativa reiterada e de amplo conhecimento público" (BRASIL, 2018).

${ }^{15}$ A definição de orientações gerais contida na LINDB é considerada "insuficiente para dirimir todas as dúvidas que poderão existir na aplicação desse conceito aos casos concretos. A existência de posicionamentos divergentes dentro de uma mesma estrutura administrativa ou mesmo a divergência jurisprudencial em tribunais pode levar a questionamentos quanto à identificação da existência de 'orientação geral' sobre algum tema" (CÂMARA, 2018, p. 131).
} 
No encerramento deste grupo, o artigo 28 da LINDB assegura que "o agente público responderá pessoalmente por suas decisões e opiniões técnicas em caso de erro grosseiro" (BRASIL, 2018). Coadunado com a jurisprudência do Superior Tribunal de Justiça, como "espécie de cláusula geral do erro administrativo", o dispositivo delimita a responsabilidade do agente às hipóteses de dolo e culpa grave, esta equiparada ao erro grosseiro, reconhecido como um "código dogmático que exprime como a culpa deve ser valorada para que o agente [...] possa ser responsabilizado" (BINENBOJM; CYRINO, 2018, p. 221 e 217). Nessa direção, ao impedir a esfera controladora de se ancorar na culpa presumida (in re ipsa), protege o gestor "inábil, porém íntegro" (DINIZ; DINIZ, 2018, p. 295), contrapondo-se à "noção persecutória de que toda falha na aplicação da lei, além de corrigida, teria também de gerar punições a seu autor" (SUNDFELD, 2019, p. 11) ${ }^{16}$. Entende-se que, "seguro de que não será responsabilizado, salvo por dolo ou erro grosseiro, o gestor público pode inovar na gestão pública" (PALMA, 2020, p. 235, grifo do autor).

\subsection{As normas específicas de Direito Administrativo}

Pelo objeto conexo e restrito a termos de compromisso (acordos público-privados) e instrumentos de compensação, os artigos 26 e 27 da LINDB demarcam situações próprias do Direito Administrativo, razão pela qual cogita-se que poderiam ter integrado "leis esparsas que hoje regulam tópicos específicos” (ANDRADE, 2019, p. 129).

O artigo 26 "pressupõe a negociação do exercício de determinada prerrogativa pública pelo Poder Público com o particular e a celebração por acordo de vontades no âmbito de um processo administrativo" (GUERRA; PALMA, 2018, p. 148) ${ }^{17}$. Na observância do interesse público ou geral, o apreço ao consensualismo na solução do Direito em litígio corrobora a prática da Administração Pública dialógica e, mediante o permissivo genérico do dispositivo, incentiva a jurisdição voluntária em substituição à imposição de autoridade unilateral.

\footnotetext{
${ }^{16}$ É válido dizer que a LINDB "não está preocupada com o gestor de má-fé. Para este, foi construída toda uma legislação de controle. Interessa-se, isso sim, pelo gestor de boa-fé, cujo comportamento honesto não é tutelado pelo Direito e termina por receber o mesmo tratamento jurídico do sujeito mal-intencionado. Por um lado, há o componente de justiça ao cidadão honesto que atua no Poder Público e busca exercer as suas competências dentro da legalidade e do modo mais eficiente possível. Porém, os fins da tutela do agente público honesto vão muito além da pessoa do gestor" (PALMA, 2020, p. 234).

${ }^{17}$ É a redação: “Art. 26. Para eliminar irregularidade, incerteza jurídica ou situação contenciosa na aplicação do direito público, inclusive no caso de expedição de licença, a autoridade administrativa poderá, após oitiva do órgão jurídico e, quando for o caso, após realização de consulta pública, e presentes razões de relevante interesse geral, celebrar compromisso com os interessados, observada a legislação aplicável, o qual só produzirá efeitos a partir de sua publicação oficial" (BRASIL, 2018).
} 
O artigo 27, por sua vez, aborda os riscos diretos e indiretos dos processos administrativos, "combatendo uma visão que sacraliza o direito ao processo e ignora seu custo e peso" (SUNDFELD, 2019, p. 11). É nesse sentido que "a decisão do processo, nas esferas administrativa, controladora e judicial, poderá impor compensação por benefícios indevidos ou prejuízos anormais ou injustos resultantes do processo ou da conduta dos envolvidos" (BRASIL, 2018). Em consonância com a racionalidade intrínseca ao CPC - artigos 79 a 95 e 302, essencialmente - e ao princípio geral do artigo 927, parágrafo único, do Código Civil 18 , “a grande novidade do art. 27 da LINDB foi viabilizar que [...] também nas esferas administrativa e controladora, em que há riscos para os direitos dos sujeitos, a autoridade redistribua esses custos e externalidades ao final do processo" (SUNDFELD; VORONOFF, 2018, p. 180). Dessa feita, o dever de compensar, se aferido, abrange não apenas as partes, como também a autoridade ou órgão decisório, seja a conduta comissiva ou omissiva.

\subsection{A hermenêutica do reforço na Lei n. 13.655/2018}

O “objetivo profundo" da LINDB, na descrição de um de seus elaboradores, está em “superar a simplificação, a legalidade do senso comum”, exemplificada pela aplicação mecânica do Direito em desconcerto com a realidade (SUNDFELD, 2019, p. 10). Nesse sentido, a discussão que antecedeu o advento da Lei n. 13.655/2018 - e persiste, como se menciona posteriormente - não foi axiológica, isto é, entre aqueles contrários ao controle da Administração (ou contra a relevância normativa dos princípios) e aqueles contrários à estabilização das relações (ou contra a relevância normativa das regras), mas acerca da "necessidade de situar os diferentes dispositivos acrescentados à LINDB e os entender, entendendo também [...] a sua pertinência" (HAEBERLIN, 2019, p. 84 e 92). Assim sendo, com o texto vigente, que não espelha inteiramente o original, é que serão construídos e apurados os seus efeitos.

Analisada em retrospecto, mesmo com o propósito de robustecer a segurança jurídica, a redação das alterações contidas na LINDB faz uso da imprecisão como técnica - supostamente justificável por se tratar de uma metanorma (PALMA, 2020, p. 231) -, tornando-se "paradoxal e ambígua" (ANDRADE, 2019, p. 126), quando não "de difícil compreensão" (DIDIER; OLIVEIRA, 2019, p. 145). Desse modo, "promete criar situações limítrofes e até embaraçosas"

\footnotetext{
${ }^{18}$ A saber: “Art. 927, parágrafo único. Haverá obrigação de reparar o dano, independentemente de culpa, nos casos especificados em lei, ou quando a atividade normalmente desenvolvida pelo autor do dano implicar, por sua natureza, risco para os direitos de outrem" (BRASIL, 2002).
} 
e, por consequência, pode ser aplicada de encontro ao objetivo jurídico projetado (ANDRADE, 2019, p. 344). Afirma-se, inclusive, que não resistiria a seu próprio crivo (OLIVEIRA, 2018b, p. 28).

Da Lei n. 13.655/2018, um artigo, um inciso e nove parágrafos foram objeto de veto do Poder Executivo por contrariedade ao interesse público e inconstitucionalidade, e, até o momento, estão sub judice os artigos 20, 21, 22 e 23, questionados pela ANAMATRA em Ação Direta de Inconstitucionalidade no Supremo Tribunal Federal (STF) ${ }^{19-20}$. Entre os argumentos, alega-se que não cabe ao Poder Judiciário "exercer juízo de futurologia sobre as consequências das decisões, ou sobre as alternativas existentes, ou sobre os obstáculos e dificuldades" em razão dos princípios regentes da jurisdição, como o da inércia (ANAMATRA, 2019, p. 3).

A despeito das múltiplas leituras e disputas que os artigos da Lei n. 13.655/2018 ensejam, há nelas um ponto em comum: na exegese juspublicística, a LINDB não representa, propriamente, uma inovação ou ruptura, mas antes o condão de reforçar normas de Direito Público, de "positivação das melhores práticas" (MARQUES NETO; MOREIRA, 2015, p. 12), de "consolidar fórmulas já assentes" (CÂMARA, 2018, p. 122) e "consolidar tendências", de "ampliar os horizontes de soluções particularizadas" (DUQUE; RAMOS, 2019, p. 36) e generalizar "experiências já em curso na gestão pública” (PALMA, 2020, p. 243). Nesse caminho, em maior ou menor grau, os novos dispositivos refletem outros positivados no ordenamento ou selecionam métodos e técnicas que há tempos figuram como questão jurisprudencial e doutrinária, de modo a "impor aos órgãos de controle e aos operadores do Direito em geral a implementação dos avanços científicos" (MARTINS, 2020, p. 261). Nada obstante, como aludido, "o êxito da nova LINDB depende, sobremaneira, [...] da busca de soluções constitucionalmente adequadas para resolução de problemas concretos da atividade administrativa, controladora e judicial” (DUQUE; RAMOS, 2019, p. 36).

A toda evidência, não compete ao controlador pavimentar o caminho futuro para o gestor, mas, por certo, deve considerar a viabilidade das atividades administrativas, eventualmente obstadas pelo conteúdo da decisão de controle.

\footnotetext{
${ }^{19}$ Respectivamente, os vetos opostos pelo Presidente da República direcionaram-se ao artigo 25 (composto de três parágrafos), que facultava o uso da Ação Civil Pública para obtenção de provimento jurisdicional declaratório da validade de ato administrativo, com efeito erga omnes; ao inciso II, contido no $\S 1^{\circ}$ do artigo 26 ; ao parágrafo único do artigo 23; ao $\S 2^{\circ}$ do artigo 26; aos três parágrafos do artigo 28; e, por fim, ao $\S 2^{\circ}$ do artigo 29.

${ }^{20}$ Trata-se da Ação Direta de Inconstitucionalidade n. 6146, de relatoria do Ministro Nunes Marques (em substituição ao Ministro Celso de Mello), cujo trâmite está disponível em: https://portal.stf.jus.br/processos/detalhe.asp?incidente=5702503. Acesso em: 25 out. 2021.
} 
DINIZ, Cláudio Smirne; MENDES, Rullyan Levi Maganhati. O primado da realidade na lei de introdução às normas do direito brasileiro

\section{0 artigo 22, caput, da Lei n. 13.655/2018 e o primado das realidades}

$\mathrm{Na}$ hermenêutica do reforço trazida pela Lei n. 13.655/2018 e, mais precisamente, no arranjo de reciprocidade realista dos novos dispositivos, o tratamento que privilegia o primado da realidade é flagrante no caput do artigo 22, que contém "possivelmente o maior entrave interpretativo da dinâmica introduzida pela nova lei introdutória” (BERTOLIN, 2018, p. 198), e, por essa razão, interessa analisá-lo de forma mais detida.

De acordo com o texto legal - repisa-se -, "na interpretação de normas sobre gestão pública, serão considerados os obstáculos e as dificuldades reais do gestor e as exigências das políticas públicas a seu cargo, sem prejuízo dos direitos dos administrados" (BRASIL, 2018). Trata-se, consoante adiantado, de uma norma geral de Direito Administrativo, cujo escopo material é demarcado pela referência a gestão pública, gestor e administrados (ANDRADE, 2019, p. 187).

Universalmente aplicável às instâncias administrativa, controladora e judicial, o dispositivo obriga todo intérprete de normas de gestão pública, porém, com efeito, "pretende reagir à cultura do hipercontrole público" (MENDONÇA, 2018, p. 45, grifo do autor) e, consequentemente, arrefecer a paralisia decisória da Administração - o chamado apagão das canetas -, cenário em que, dada a intensidade de controle suportada pelo gestor e o alto risco de sua atuação ser reputada ilícita, a inércia torna-se a escolha mais vantajosa, ainda que "servil e, por vezes, medrosa e covarde" (BATISTA JÚNIOR; CAMPOS, 2014, p. 38) ${ }^{21}$. Nessa compreensão, "o sistema de controle é insensível aos obstáculos e às reais dificuldades do gestor", de modo que "as decisões administrativas assemelham-se a uma 'primeira tentativa', cuja deliberação final depende do aval do controlador" (PALMA, 2020, p. 217).

A LINDB, nesse liame, está orientada a "inibir o controle que obstaculiza em demasia o agir administrativo" (CUNDA, 2019, p. 64) e, para tanto, o exercício da função dos órgãos controladores deverá levar em conta a realidade jurídico-administrativa do gestor fiscalizado.

Coube ao artigo 22, caput, comportar o imperativo de "impor certa carga eficacial à realidade, determinando que ela seja lida em compasso com a aplicação das regras jurídicas” (HAEBERLIN, 2019, p. 86), exigente, decerto, da construção de um ““diálogo’ [...] notoriamente bastante complexo" (MAFFINI; HEINEN, 2018, p. 255), apto o bastante a

\footnotetext{
${ }^{21}$ Argumenta-se, em contraponto, que a "insegurança jurídica, ineficiência e paralisia [fortes déficits institucionais de governança e de gestão] são problemas cujas soluções [...] estão dentro da própria Administração Pública e não nos órgãos de controle, nem muito menos no afastamento do controle ou no afrouxamento das regras de responsabilização de agentes públicos" (OLIVEIRA, 2018b, p. 34-35).
} 
legitimar "o texto [...] além do texto" (FREITAS, 2004, p. 23) em consonância com os fins sociais e as "evidências do real" (SUNDFELD, 2019, p. 11). Nesse ensejo,

É preciso que o intérprete desloque-se do egocentrismo legislativo e reconheça que a lei não é a fonte primária do Direito. Sua fonte primária são os fatos. Mitigar os efeitos da lei de acordo com a realidade, temperar a generalidade (abstração ínsita à atividade legislativa) com a especificidade (fatos concretos), colmatar lacunas, notadamente aquelas decorrentes da complexidade, todas essas tarefas são, dentre outras, tarefas naturais do intérprete contemporâneo, as quais veem-se agora prescritas no art. 22, caput e parágrafos, da LINDB (HAERBELIN, 2019, p. 90).

Diante desse enquadramento, ao prescrever uma interpretação pragmática e contextualizada, o mérito do artigo 22, caput, estaria no enfrentamento de duas "teorias românticas (ou idealistas)", a que supervaloriza o Direito (operador, em cada decisão pública, de soluções autorreferentes e pretensamente unívocas) e a que idealiza os fatos, "as condições materiais, factuais e objetivas para que a Administração Pública realize os ambiciosos projetos do Direito Público nacional" (JORDÃO, 2018, p. 66 e 68).

Dessa maneira, no intuito de estabilizar as relações, a LINDB incorpora em sua redação, ao lado do caráter abstrato, idealístico e prospectivo inerente à ciência jurídica (o dever ser) pressuposto de modificação da realidade -, a preferência por circunstâncias contextuais na realização do Direito, isto é, a consideração da realidade em recorte concreto e atual (o ser), dinâmica que, prolongada ou a depender da situação, pode autorizar uma lógica de que os fins justificam os meios, guardar certa proximidade com o reconhecimento de fatos consumados e, no limite, possibilitar "o raciocínio de que a realidade vence o Direito" (NOHARA, 2018a, p. $34)$.

É nesse lastro o argumento de que o caput do artigo 22 "promove a interpretação casuística, pois [...] o alcance e os limites da norma devem ser definidos em cada caso" (OLIVEIRA, 2018b, p. 53), ofertando abertura para "fulminar com o controle escorreito dos atos administrativos praticados pelos gestores" e, em visão crítica, constituir "um fomento para a impunidade" (HAEBERLIN, 2019, p. 81). Nessa percepção, ao “incluir parâmetros exegéticos mais benevolentes ao administrador e [...] dificultar o controle sobre os atos praticados", inauguraria "um microssistema jurídico específico do gestor público, distante dos comandos constitucionais” (MINISTÉRIO PÚBLICO FEDERAL, 2018, p. 7) 22.

\footnotetext{
${ }^{22}$ A esse respeito: "Em críticas dirigidas ao artigo 22, diz-se que ele promoveria uma flexibilização casuística. A tais críticos, caberia perguntar: é legítima uma interpretação jurídica que não considera a realidade? A resposta é, claramente, negativa. Como dizia Ortega y Gasset, em conhecida reflexão: '[y]o soy yo y mi circuntancia, y si no la salvo a ella no me salvo yo'. Do mesmo modo, o agente é ele e suas circunstâncias, e essas devem ser levadas em consideração na interpretação das regras de Direito Público e na imposição de sanções" (HAEBERLIN, 2019, p. 92-93).
} 
Ao "particularizar, ao extremo, e em favor de cada gestor de modo individualizado, o exame das possibilidades fáticas" (OLIVEIRA, 2018b, p. 59) da Administração e de concretização de políticas públicas, a LINDB, em verticalidade, traz a lume as distintas realidades dos 5.570 municípios brasileiros e suas profundas diferenças territoriais, demográficas, funcionais, sociais, ambientais e econômicas, também inseridas, por sua vez, em um cenário de desigualdades intra e inter-regionais ${ }^{23}$.

Nesse prisma, se o ordenamento prescreve "condutas imperativas (e dotadas de coercibilidade), em razão de valores considerados relevantes” (GARCIA, 2020, p. 42, grifo do autor), deve-se construir uma dinâmica em que "o primado da realidade não seja obstáculo à realização do Direito" (NOHARA, 2018a, p. 33), daí a ponderação de que o caput do artigo 22 oferece "um comando de sensibilização do controlador à realidade da burocracia pública brasileira" (PALMA, 2020, p. 229, grifo do autor).

Assim sendo, estabelecido no campo inferencial, o ônus do administrador pode ser analisado sob duas perspectivas (muitas vezes, sobrepostas), a dos obstáculos jurídicos, isto é, da "dificuldade de interpretar a legislação relevante para entender o que ela determina, veda ou possibilita", e a dos obstáculos materiais, dos fatos em concreto, da "maior atenção às agruras e aos dilemas do gestor público" ante a primazia das realidades administrativas (JORDÃO, 2018, p. 77 e 70).

É, a esse respeito, o conteúdo das subseções a seguir.

\subsection{Os obstáculos jurídicos do gestor: da "geleia geral" à solidez prática}

Sucedeu, da Lei de Introdução ao Código Civil Brasileiro de outrora à recente publicização da LINDB, um conjunto de agudas transformações sociopolíticas no Direito. Hoje revisto pelo fundamento e eixo constitucional, passou a ser informado por um "sistema aberto e flutuante, mais de natureza teleológica do que de natureza lógica” (BONAVIDES, 2004, p. 285), contexto, em rótulo genérico, denominado de pós-positivismo, no qual são exercidas “a centralidade dos direitos fundamentais e a reaproximação entre Direito e ética" (BARROSO, 2007, p. 223).

\footnotetext{
${ }^{23}$ Nessa linha de raciocínio: "O art. 22, no campo, por exemplo, da gestão fiscal, agravaria ainda mais a caótica situação fiscal de diversos Estados e Municípios brasileiros cujos gestores, com as atuais regras, já foram capazes de deteriorar ao extremo a higidez das finanças públicas, com drásticas repercussões nos direitos fundamentais dos cidadãos, face a precariedade dos serviços públicos prestados, e dos próprios servidores públicos que, em alguns Estados da Federação, com frequência recebem com atraso de meses o pagamento de seus salários" (OLIVEIRA, 2018b, p. 55).
} 
O Direito brasileiro pós-1988 “alenta um ideário humanista, que aposta na possibilidade de emancipação [...] pela via jurídica", veiculada sobretudo pela valorização dos princípios normativos e pela "adoção de métodos ou estilos mais [...] flexíveis na hermenêutica" (SARMENTO, 2010, p. 244 e 252). Verifica-se, no neoconstitucionalismo atual, igualmente aqui em referência lato sensu, que o estrito legalismo deve ser suplantado pela juridicidade, concepção que alcança o ordenamento jurídico e dele prospecta um todo de sentido constitucionalmente sustentado, a "obediência não somente à lei, mas também ao Direito" (MAFFINI, 2019a, p. 42). Nesse lanço, texto e norma não mais se confundem, "na medida em que o primeiro passa a ser apenas o ponto de partida e, assim, o atingimento da norma completa dar-se-á após o percurso do caminho da interpretação" (DINIZ; DINIZ, 2018, p. 277).

Nessa condição, exposta de relance, acentua-se o problema da indeterminação dos valores jurídicos abstratos, admitido como "uma constatação objetiva" e "uma inevitabilidade" (JORDÃO, 2018, p. 66), do qual os princípios normativos são ilustração. Todo valor jurídico abstrato oportuniza um suporte fático amplificado, a saber, “quanto mais vago [...], maior o seu potencial para produzir razões multidirecionais" (LEAL, 2016, p. 26). Junto a isso, “a pluralidade de intérpretes [...] torna a norma tanto mais legítima, quanto fluida" (DINIZ; DINIZ, 2018, p. 280).

Por esse ângulo, normatizada, a riqueza semiótica da linguagem - sem descuidar do texto como limite - é capaz de fragmentar e até mesmo despistar o "direito relevante" (JORDÃO, 2018, p. 77) no caso concreto, ao passo que também se presta a "parâmetro de controle, não de libertação" (VITORELLI, 2020, p. 82), comprometendo a estabilidade relativa do Direito. Em rigor, na dependência do modo como é exercida, a invocação a valores jurídicos abstratos e, sobretudo, a princípios, pode afastar determinações textuais expressas e completas e, como expediente retórico, "obter a aprovação para uma decisão pessoal da autoridade" (JUSTEN FILHO, 2018, p. 26). Em descrição provocativa, o quadro é de "um ambiente de 'geleia geral' [...], em que princípios vagos podem justificar qualquer decisão" (SUNDFELD, 2017, p. 205).

Nesse aspecto, tanto o exercício livre e maleável da linguagem jurídica, posto que frequentemente "o mundo das palavras possui vida" (NADER, 2020, p. 75), quanto a complexidade da contínua produção legislativa são, per se, problemas da realidade enfrentados pelo intérprete. O Direito não é imune às contradições e não abarca toda a casuística. Assim, não se pode negligenciar que, das dificuldades vivenciadas pelo gestor, muitas correspondem “a uma séria e fundada dúvida jurídica” (JORDÃO, 2018, p. 77) e, desse modo, “o Direito só 
serve de mecanismo de orientação se o destinatário consegue compreendê-lo" (DIDIER; OLIVEIRA, 2019, p. 145).

Toma-se como amostra a própria Lei n. 13.655/2018, que, tão somente com uma dezena de artigos, faz uso de mais de trinta conceitos jurídicos indeterminados, entre eles, os termos concernentes aos obstáculos e às dificuldades reais do gestor público, empregados na cabeça do artigo 22, presumivelmente "passíveis de levar os processos de responsabilização por caminhos insondáveis” (MINISTÉRIO PÚBLICO FEDERAL, 2018, p. 6).

A situação é visivelmente mais crítica quando se releva que a Administração, “considerando a extensão da máquina pública e suas múltiplas atribuições", é "a maior intérprete do Direito" (PALMA, 2020, p. 227) e, como sabido, titular de práticas estatais típicas e atuação direta ou indireta em setores econômicos estratégicos, bem como vinculada à efetivação de direitos fundamentais (vilipendiados, por vezes, pela provisoriedade de sentido da norma). Portanto, como "a relação da Administração com a lei não é de submissão passiva, mas de conformação ativa” (GUIMARÃES, 2019, p. 342), “administrar é interpretar normas públicas para aplicação em casos concretos. Especialmente no caso brasileiro, em que as leis dirigidas à Administração são pouco detalhistas e prenhes de indeterminação jurídica, a interpretação é uma tarefa indissociável da implementação" (PALMA, 2020, p. 227, grifo do autor $)^{24}$.

Dessa forma, na intenção de aprimorar a gestão pública brasileira servindo como enforcement à segurança e eficiência do ordenamento, a LINDB diferencia-se por enfrentar "entraves jurídico-culturais", isto é, "a forma como o Direito [...] vem sendo interpretado e aplicado - principalmente, mas não exclusivamente, pelos controladores" (JORDÃO, 2018, p. 65, grifo do autor). Note-se que não é contrária “a princípios ou a conceitos jurídicos indeterminados, mas coloca em perspectiva o modo como são empregados" (PALMA, 2020, p. 231, grifo do autor), ou seja, adverte para "que toda e qualquer decisão proferida por autoridade pública, inclusive a controladora, seja fruto de atividade racional” (DUQUE; RAMOS, 2019, p. 30), por isso a "determinação, até mesmo repetitiva, de que a realidade, ou melhor, os fatores

\footnotetext{
${ }^{24}$ Em exposição bastante didática: "A professora da escola primária interpreta o programa curricular básico para construir uma aula mais próxima à realidade regional de seus alunos. O médico toma decisões trágicas considerando o cenário de escassez que solapa a saúde pública. O colegiado da ANVISA [Agência Nacional de Vigilância Sanitária] interpreta o texto da lei para determinar se narguilé é um produto fumígeno para fins de regulação. O IBAMA [Instituto Brasileiro do Meio Ambiente e dos Recursos Naturais Renováveis] analisa se expede licença ambiental para um determinado projeto de empreendimento a partir da interpretação de conceitos jurídicos indeterminados como 'efetiva ou potencialmente poluidoras' e 'degradação ambiental'. O perito da Previdência Social interpreta as normas para conceder, ou não, benefícios previdenciários. O gestor público interpreta a Lei n. 8.666/93 para ponderar se uma determinada situação é hipótese de dispensa de licitação" (PALMA, 2020, p. 227).
} 
reais e pragmáticos existentes devem ser sempre levados em conta" (MAFFINI; HEINEN, 2018, p. 255). Em outros termos, densifica - e rememora - a noção de que "há, no universo jurídico, uma 'vontade axiológica do sistema' [...], que age no sentido de encontrarmos as respostas sempre num mutualismo do ato de conhecer entre intérprete, realidade e ordenamento" (HAEBERLIN, 2019, p. 87).

Logo, quando do acionamento de valores abstratos como base decisória, a Lei n. 13.655/2018 atribui, a "quem quer que seja" (PALMA, 2020, p. 245, grifo do autor), o "dever de motivação qualificado" (ANDRADE, 2019, p. 155) por um viés pragmático, realista e consequencialista, notadamente aferível pela tríade dos artigos 20, 21 e 22, estabelecendo uma nova "gramática da decisão" (MENDONÇA, 2016, p. 33, grifo do autor) ${ }^{25}$. O que se desautoriza, portanto, é “que a utilização de tais 'valores jurídicos abstratos' ocorra de modo descompromissado com as consequências práticas da decisão" (MAFFINI; HEINEN, 2018, p. 253). Dessa maneira,

Os artigos 20 e 22, somados ao art. 21 da LINDB, tornam mais robusto o "ônus argumentativo" tanto das "causas" como das "consequências" do ato decisório, que em muitas situações fáticas não será um ato isolado, mas inserido em um "ciclo decisório" (com atos de planejamento, execução e controle) que deverá estar na íntegra submetido aos mandamentos de "consideração da realidade" $e$ “consideração das consequências” (CUNDA, 2019, p. 70, grifo do autor).

Em cômputo, no prestígio da experiência técnica, ao determinar que sejam expressas as relações de causalidade na decisão, a LINDB reafirma o cerne responsivo das atividades administrativas, quer dizer, "reforça a essencialidade do planejamento das ações [...], a fim de que sejam produzidas consequências desejadas pela Constituição Federal e de modo a se evitar a produção de consequências não admitidas pelo Direito" (OLIVEIRA, 2018b, p. 50). Do mesmo jeito, são inadmissíveis "ações impensadas, populistas, que tenham efeitos maléficos de longo prazo na implementação das políticas públicas” (JORDÃO, 2018, p. 72).

Nesse sentido, como as consequências da incerteza do Direito não devem ser suportadas pelo gestor na condução de seu plexo de deveres e responsabilidades, em caso de vultosa interrogação jurídica, a LINDB aponta dois caminhos que podem ser adotados pela Administração Pública. O primeiro, endereçado às autoridades hierarquicamente superiores, diz respeito à edição de regulamentos ou súmulas que informem a interpretação a ser seguida, conforme prevê o artigo 30. Diante da inexistência de ato regulamentar com esse fito, o segundo

\footnotetext{
25 Essa nova gramática decisória tangencia a metodologia analítica de escolhas conhecida como Análise Econômica do Direito (AED), aportada no Brasil no início dos anos 1980. A AED, que não é uma teoria da justiça, pleiteia escolhas racionalmente maximizadas (úteis), na diagnose de que cada seleção carrega em si um custo de oportunidade (trade-off). Nesse sentido, "faz a decisão que será tomada depender da informação disponível das opções e consequências" (MACKAAY; ROSSEAU, 2015, p. 32).
} 
caminho é a manifestação da dúvida encontrada. Nessa situação, deve o gestor público "motivar a sua atuação indicando claramente quais dificuldades interpretativas identificou, quais escolhas interpretativas adotou e por qual razão", à luz do caso concreto (JORDÃO, 2018, p. 77-78). Evita-se, com esses modos de proceder, a punição do gestor pelo chamado crime de hermenêutica, a saber, que "seja sancionado por conta de ofertar uma interpretação razoável do Direito, ainda que não seja aquela que o agente controlador considere a melhor" (HEINEN, 2019, p. 168). Do lado da esfera controladora, nos termos do artigo 22, caput, a dificuldade jurídica do gestor terá de ser sopesada; se existente e plausível, irá repercutir no controle, isto é, “tratar-se-á apenas de permitir interpretações igualmente razoáveis e igualmente lícitas, em função de dificuldades jurídicas ou interpretativas" (JORDÃO, 2018, p. 80).

No acabamento deste excerto, interessa cogitar que o primado da realidade aplicado às decisões que têm base em valores jurídicos abstratos representa, em síntese, uma orientação tautológica. Se os princípios normativos, em especial, carregam um telos, um caráter finalístico, e requisitam a concretização de algo segundo as possibilidades fáticas e jurídicas (CANOTILHO, 2002, p. 1.255), então a tomada de decisão “deveria necessariamente envolver um juízo sobre os possíveis efeitos atrelados à aplicação de medidas destinadas a realizar os estados de coisas a eles vinculados". Nesse entendimento, de forma redundante - ou na perspectiva hermenêutica do reforço trazida pela LINDB -, caracteriza um mero comando para que as "normas sejam aplicadas como deveriam" (LEAL, 2016, p. 27-28).

\subsection{Os obstáculos da Administração Pública: do medo à empatia}

Além das dificuldades atinentes à interpretação da norma, a LINDB também se preocupou com as limitações fáticas e materiais que impedem o gestor de boa-fé de implementar o Direito, de modo a contemplá-las na hermenêutica jurídica mediante fundada contextualização. Seria, nesse sentido, "a forma mais realista (e, portanto, mais eficaz) de tirar as promessas jurídicas do discurso, para levá-las à realidade” (JORDÃO, 2018, p. 69).

O caput do artigo 22 da LINDB, em apreciação à heterogeneidade multinível da Administração Pública e, nela, à escassez de recursos e aos custos do Direito, "produz uma espécie de 'pedido de empatia' com o gestor público e com suas dificuldades", passando a encerrar o fundamento normativo das teorias de deferência inseridas no ordenamento brasileiro (JORDÃO, 2018, p. 70 e 78).

Propõe, nesse espeque, que o "Direito Administrativo do medo" (MAFFINI, 2019b, p. 115), fonte de pretenso imobilismo do gestor, seja institucionalmente decantado por "um 
respeito pela diferença” (HEINEN, 2019, p. 167) e, por conseguinte, permeado por vínculos de comunicação e alteridade entre executores e revisores. Dessa forma, o controlador deve levar em conta as circunstâncias fáticas da gestão pública interferentes na interpretação administrativa ${ }^{26}$. Descumprido o ônus argumentativo pelo controlador, a interpretação razoável do gestor ante as dificuldades práticas merece deferência e validação, isto é, "as circunstâncias fáticas limitadoras [...] passarão a compor a hipótese fática complexa cuja regulação será identificada pelo controlador no Direito" (JORDÃO, 2018, p. 80).

Suscita-se, nessa dinâmica, o risco de se transformar os órgãos judiciais e de controle em órgãos de consultoria jurídica administrativa ${ }^{27}$. Em abstrato, o artigo 22, caput, da LINDB, dirigido ao gestor, dele não retira ou transfere qualquer incumbência e ônus probatório, porém requisita - como figura de linguagem - que o controlador "se imagine" na posição do tomador de decisão (JORDÃO, 2018, p. 72). Ainda, é de se perceber que a exigência da conduta deferente que se extrai da LINDB repercute diretamente na atuação controladora, impondo condições à tomada de decisão ${ }^{28}$. Essa constatação, no entanto, é compartilhada por todos os agentes com recursos de poder, posto que "são condicionados, afinal, pela realidade". Vislumbra-se, nesse exame, "que o debate sobre a Lei n. 13.655/2018 não é um debate sobre a Lei n. 13.655/2018. O pano de fundo da questão é, em verdade, um debate sobre a jurisdição e seus limites" (HAEBERLIN, 2019, p. 93).

A determinação realística inserida no caput do artigo 22 relaciona-se, por excelência, às teses de limitação e vinculação do orçamento público e, consequentemente, às omissões estatais por elas justificadas. Por sua vez, quando da judicialização de políticas públicas, é longevo o debate sobre as restrições das finanças públicas com base na famigerada dicotomia entre a reserva do possível e o mínimo existencial ${ }^{29}$, resultante da "equação entre uma necessidade quase infinita de bens que o Estado deve prover aos cidadãos e os recursos orçamentários finitos do Estado para prover esses bens" (HAEBERLIN, 2019, p. 90). Nesse sentido, na aplicação do

\footnotetext{
${ }^{26}$ Logo, se a atuação do gestor ocorreu "segundo os meios e instrumentos de que dispunha, e os elementos que usou para interpretar a realidade encontram-se traduzidos e incorporados em documentos e outros meios de prova, o órgão de controle deverá levar em conta esses elementos e esses meios de prova, sem prejuízo de sua própria atuação, no sentido de confrontá-los dialeticamente com outras provas, ou novos modos de interpretar as já existentes" (NOGUEIRA JÚNIOR, 2019, p. 44).

${ }^{27}$ Um dos principais argumentos contrários à Lei n. 13.655/2018, contido nas manifestações do MPF, TCU e ANAMATRA.

${ }^{28}$ Novamente, em oposição à Lei n. 13.655/2018, preocupação externada nas manifestações do MPF, TCU e ANAMATRA.

29 À luz da LINDB, o conteúdo da reserva do possível vai ao encontro dos obstáculos e dificuldades reais do gestor e das exigências das políticas públicas a seu cargo - como as materiais, temporais, orçamentárias, ambientais, de pessoal -, ao passo que o mínimo existencial diz respeito a um patamar básico e irredutível de garantia de direitos dos administrados (DINIZ; DINIZ, 2018, p. 287).
} 
Direito, o gestor público, à margem de seu arbítrio, é obrigado a cumprir escolhas valorativas e alocativas de bens constitucionais - não raro, as chamadas escolhas trágicas -, isto é, “a escassez de recursos públicos impõe sacrifícios, impedindo que se resolvam todos os anseios da sociedade, por mais imprescindiveis que sejam" (MAFFINI; HEINEN, 2018, p. 257, grifo do autor).

Caso emblemático dessa situação é o da judicialização da saúde. Prevalece, no Estado brasileiro, o entendimento doutrinário e jurisprudencial de que o direito social à saúde lastreado em uma espécie de "teoria moral da santidade da vida como valor jurídico" (PIAZENSKI; AGUIAR, 2017, p. 383) - se sobrepõe aos demais, sendo "juridicamente irrelevantes" ou de importância secundária as condições materiais para implementá-lo (JORDÃO, 2018, p. 68-69), sem que haja devida verticalização quanto aos efeitos que múltiplas decisões individuais causam nas políticas públicas de saúde.

O primado da realidade espraiado pela LINDB - e, em expressão categórica, no caput do artigo 22 - propõe justamente a inversão desse estado de coisas, pugnando, pela via normativa, por uma filtragem pragmática do Direito, na qual as "“escolhas' possuem parâmetros" e "as razões de decidir deverão ser claras no sentido de dar ênfase às consequências de se optar por uma e não por outra via, bem como no que isso impacta na realidade do Poder Público e do cidadão" (MAFFINI; HEINEN, 2018, p. 255). É dizer: "não se pode reconhecer um direito subjetivo exclusivo, abstrato e excludente de cada indivíduo se não contextualizado com as peculiaridades da esfera pública de deliberação" (FERREIRA; XIMENES, 2016, p. 814). Assim, as escolhas do gestor devem ser nitidamente estimadas pelas consequências e pela realidade do quadro estrutural do Estado. Em suma, "há de se ter uma renúncia às escolhas do que gostaríamos para aquilo que socialmente é justo e real - sendo esta a teleologia da Lei n. 13.655/2018" (MAFFINI; HEINEN, 2018, p. 256).

O artigo 22, caput, da LINDB, todavia, não exime a Administração do fornecimento eficiente de bens e serviços públicos, muito menos dispensa o gestor do cumprimento dos fins arrolados pela Constituição da República ou, até mesmo, representa um salvo-conduto para que seja desonerado do controle de seus atos (JORDÃO, 2018, p. 74). Traz à juridicidade, porém, "o fato de que o agente público não possui a condição de torcer o espaço-tempo, modificando a realidade" (HAEBERLIN, 2019, p. 92). Seu propósito não é o "de violar a lei, mas de interpretá-la inteligentemente ou adequadamente" (JORDÃO, 2018, p. 81) e, por isso, "reconhece a capacidade e a possibilidade de o gestor fazer escolhas, apenas exigindo que as faça com responsabilidade", o que significa "medir as consequências do que se pretende fazer" (SOUZA; ALENCAR, 2019, p. 66-67). Nesse raciocínio, 
[...] a aplicação do primado da realidade não implica desconsiderar o Direito e sua cogência, mas de procurar realizar um sopesamento de critérios para que haja a enunciação de uma decisão mais equilibrada e cujos efeitos sejam individualizados em função das particularidades do caso concreto, suas vicissitudes e os impactos tanto no tocante aos direitos dos indivíduos afetados, como na realização dos interesses públicos (NOHARA, 2018b, p. 203).

Configura-se, assim, uma ressignificação interna do ordenamento, "uma tentativa de aterrar" o Direito (ANDRADE, 2019, p. 142-143) na atribuição de peso interpretativo, integrador e dialogístico para a "consideração da realidade como fator determinante, como fator primeiro, deixando-se de lado a orientação 'normativista', redutora dos próprios direitos" (MAFFINI; HEINEN, 2018, p. 258), mesmo porque "a Administração tem compromissos com a realidade que não podem ser ignorados, como sugere o próprio princípio da eficiência" (GUIMARÃES, 2019, p. 349).

Nesse caminho, em uma perspectiva de legitimidade procedimental, a consideração da realidade deve ser aferida e graduada, já que "nem toda dificuldade ou obstáculo real que tenha existido durante a ação ou omissão administrativa [...] será relevante" (JORDÃO, 2018, p. 76, grifo do autor). Dessa maneira, por mais que a norma persiga "algum controle sobre o controle" (HAEBERLIN, 2019, p. 93), sem desvirtuar atribuições e competências, "a última palavra sobre a validade do ato sob controle segue sendo do controlador, e dependerá dele a efetiva consideração das circunstâncias limitadoras da ação do gestor" (JORDÃO, 2018, p. 74) ${ }^{30}$.

Com efeito, ainda que construindo paradoxos arriscados, o que a Lei n. 13.655/2018 propõe é o exercício do Direito em narrativas menos retóricas, subjetivas e conceituais, com assento privilegiado nas possibilidades e ingerências da realidade vivida (o que impede desestima com os demais saberes), de modo a manter o ânimo constitucional e concretizador do dever ser, porém sem restringi-lo a um monólogo insulado, em que esfera for. No limite, é um plano que pretende reforçar e qualificar o controle, mas, em sua extensão, volta-se em igual medida para o comportamento dos que se relacionam com o Poder Público e o tornam instituto, distribuindo os ônus da escolha pública. Como o Direito não nasce da lei, "mas sim da vida (e nela se desdobra)" (MARQUES NETO; MOREIRA, 2015, p. 11), é certo que nele "a contingência humana [...] impõe adequações, temperamentos e adaptações" (SILVA, 2015, p. 20) A LINDB, nesse reconhecimento, avigora a segurança jurídica como função, fim e valor no dever decisório, articulando-a com a concretude das circunstâncias. E reitera, no trecho

\footnotetext{
${ }^{30}$ Em termos assemelhados, "não significa que o apontamento de contextos, a exemplo 'de obstáculos e dificuldades reais', possa servir de escudo legitimador para decisões equivocadas. Significa apenas que tais elementos merecem devida consideração, inclusive pelas autoridades de controle, a quem fica reservado o juízo derradeiro a respeito de sua suficiência ou seu acatamento perante a lei" (SOUZA; ALENCAR, 2019, p. 67).
} 
DINIZ, Cláudio Smirne; MENDES, Rullyan Levi Maganhati. O primado da realidade na lei de introdução às normas do direito brasileiro

inicialmente cumprido, o quanto a realidade, no Direito, é de singela enunciação e complexa mediação.

\section{Considerações finais}

Desde o trâmite no Congresso Nacional, a Lei n. 13.655/2018 é perquirida a respeito do propósito integrado por cada um de seus dez dispositivos. Inseridos na LINDB, os artigos 20 a 30 - vetado o 25 - representam a positivação de posturas defendidas ou praticadas na literatura e na jurisprudência do Brasil, sob variadas influências. Argumenta-se, de um lado, que os novos dispositivos servem ao enfraquecimento dos órgãos de controle e do Poder Judiciário (mitigando, a reboque, os recursos contramajoritários de poder) e, de outro, que promovem a empatia relacionada a uma espécie de imobilidade jurídico-constitucional da Administração Pública, imersa na fluidez hermenêutica do Direito e submetida a rigoroso e subjetivo controle. Nesse contexto, a intentio oficial da Lei n. 13.655/2018 comunica o incremento da segurança e eficiência jurídicas no Direito Público, que, do cotejo de seus artigos, engendra-se mediante a diretriz normativa do primado da realidade, neles espraiada.

Tomado como problema de pesquisa, o texto posto da Lei n. 13.655/2018, de abrangência nacional, resultou repleto de conceitos indeterminados e numerosos espaços sem regulamentação. Se, como préstimo, trouxe a lume a discussão sobre a qualidade jurídica das decisões públicas e sobre as dificuldades materiais enfrentadas sob a ótica do gestor de boa-fé, tornou-se, no somatório de pontos de ambivalência e contradição, um problema teórico e empírico a ser equalizado. Dado o tempo relativamente curto de sua vigência, é prematuro exigir uma base formada de jurisprudência que o impulsione, quer administrativa, quer judicialmente. Nesse lanço, o conteúdo da diretriz do primado da realidade também pende de construção.

Em acepção jurídica, o primado da realidade pode ser informado por correntes teóricas de distintas vocações e escalas, das mais emancipatórias àquelas ofensivas às dignidades. Com status de norma daqui por diante, o pragmatismo, embora operado até mesmo pelo STF em julgamentos recentes, não é uma tradição no Direito brasileiro, de modo que terá de ser consensualmente delimitado e embutido de sentido. O caput do artigo 22 , expressão máxima do pragmatismo na LINDB, se exercido de forma não republicana, pode ser instrumento de preocupante arbítrio - ideia antitética ao Estado Democrático de Direito - e de insuspeita atribuição de legalidade a situações frontalmente violadoras de direitos. Diante dessa perspectiva, postula-se a consideração provisória das dificuldades reais da gestão pública sem 
DINIZ, Cláudio Smirne; MENDES, Rullyan Levi Maganhati. O primado da realidade na lei de introdução às normas do direito brasileiro

que se perca de vista o planejamento, a execução e o controle presentificados de políticas transformadoras que beneficiem a realidade social. Quanto menor a disponibilidade de recursos financeiros, por exemplo, maior é o imperativo da escolha responsável a respeito de sua destinação.

Nesse passo, o aproveitamento da Lei n. 13.655/2018 - e de seu potencial de interpretação e aplicação - deve produzir normas em conformidade com a Constituição da República e, por conseguinte, em concordância com a autonomia e especificidade dos diferentes ramos do Direito Público nos quais incide. A diretriz do primado da realidade só é legítima se serve ao Direito constitucionalizado.

Feito o balanço crítico inicial acerca da publicização da LINDB - lugar em que este estudo se coloca -, cabe almejar que a Lei n. 13.655/2018 não se some ao rol de normas artificiais produzidas e vigentes no país, e que, assim ocorrendo, receba um enquadramento político-jurídico que genuinamente a contemple, preencha e equilibre entre os polos da gestão e do controle, em favor da cidadania e de um Direito mais confiável. Tão importante quanto os novos parâmetros hermenêuticos reunidos na LINDB, é o que deles será realmente prestado.

\section{Referências}

ANAMATRA. Ação Direta de Inconstitucionalidade. 2019. Disponível em: https://www. anamatra.org.br/images/DOCUMENTOS/2019/01-Anamatra-STF-ADI-LINDBInicial_-_Assinado_4.pdf. Acesso em: 25 out. 2021.

ANDRADE, Fábio Martins de. Comentários à Lei n. 13.655/2018: proposta de sistematização e interpretação conforme. Rio de Janeiro: Lumen Juris, 2019.

BARROSO, Luís Roberto. Neoconstitucionalismo e constitucionalização do Direito (o triunfo tardio do Direito Constitucional no Brasil). In: SOUZA NETO, Cláudio Pereira de; SARMENTO, Daniel (coord.). A constitucionalização do Direito: fundamentos teóricos e aplicações específicas. Rio de Janeiro: Lumen Juris, 2007.

BATISTA JÚNIOR, Onofre Alves; CAMPOS, Sarah. A Administração Pública consensual na modernidade líquida. Fórum Administrativo - FA, Belo Horizonte, ano 14, n. 155, p. 3143, jan./2014. Disponível em: https://www.editoraforum.com.br/wpcontent/uploads/2014/09/Administracao-Publica-consensual-na-modernidade-liquida-EditoraForum.pdf. Acesso em: 25 out. 2021.

BERTOLIN, Aline. Da previsibilidade, permeabilidade e empatia na ação administrativa. In: CUNHA FILHO, Alexandre Jorge Carneiro da; ISSA, Rafael Hamze; SCHWIND, Rafael Wallbach (coord.). Lei de Introdução às Normas do Direito Brasileiro - Anotada. v. II. São Paulo: Quartier Latin, 2018. 
DINIZ, Cláudio Smirne; MENDES, Rullyan Levi Maganhati. O primado da realidade na lei de introdução às normas do direito brasileiro

BINENBOJM, Gustavo; CYRINO, André. Art. 28 da LINDB - A cláusula geral do erro administrativo. Revista de Direito Administrativo, Rio de Janeiro, p. 203-224, nov. 2018. Edição especial. DOI: https://doi.org/10.12660/rda.v0.2018.77655. Disponível em: https://bibliotecadigital.fgv.br/ojs/index.php/rda/article/view/77655/74318. Acesso em: 25 out. 2021.

BONAVIDES, Paulo. A Constituição aberta. 3. ed. São Paulo: Malheiros, 2004.

BRASIL. Constituição da República Federativa do Brasil de 1988. Diário Oficial da União, 5 de outubro de 1988, Brasília, 1988. Disponível em:

http://www.planalto.gov.br/ccivil_03/constituicao/constituicao.htm. Acesso em: 25 out. 2021.

BRASIL. Decreto n. 9.830. Diário Oficial da União, 10 de junho de 2019, Brasília, 2019. Disponível em: http://www.planalto.gov.br/ccivil_03/_ato2019-

2022/2019/decreto/D9830.htm. Acesso em: 25 out. 2021.

BRASIL. Lei n. 10.406 (Código Civil). Diário Oficial da União, 10 de janeiro de 2002, Brasília, 2002. Disponível em: http://www.planalto.gov.br/ccivil_03/leis/2002/110406.htm. Acesso em: 25 out. 2021.

BRASIL. Lei n. 13.655. Diário Oficial da União, 25 de abril de 2018, Brasília, 2018. Disponível em: http://www.planalto.gov.br/ccivil_03/_ato2015-2018/2018/lei/L13655.htm. Acesso em: 25 out. 2021.

BRASIL. SENADO FEDERAL. Parecer (SF) n. 22, de 2017. 2017a. Disponível em: https://legis.senado.leg.br/sdleggetter/documento?dm=5205948\&disposition=inline\#Emenda9. Acesso em: 25 out. 2021.

BRASIL. SENADO FEDERAL. Recurso ao Plenário contra apreciação conclusiva das Comissões sobre o Projeto de Lei n. 7448/2017 (PLS 349/2015). 2017b. Disponível em: https://www.camara.leg.br/proposicoesWeb/prop_mostrarintegra;jsessionid=794E300C9F3E6 16AC7ECE4BC8637D18D.proposicoesWebExterno1?codteor $=1617233 \&$ filename=Tramitac ao-PL+7448/2017. Acesso em: 25 out. 2021.

CÂMARA, Jacintho Arruda. Art. 24 da LINDB - Irretroatividade de nova orientação geral para anular deliberações administrativas. Revista de Direito Administrativo, Rio de Janeiro, p. 113-134, nov. 2018. Edição especial. DOI: https://doi.org/10.12660/rda.v0.2018.77652. Disponível em: https://bibliotecadigital.fgv.br/ojs/index.php/rda/article/view/77652/74315. Acesso em: 25 out. 2021.

CANOTILHO, José Joaquim Gomes. Direito constitucional e teoria da Constituição. 5. ed. Coimbra: Almedina, 2002.

CUNDA, Daniela Zago Gonçalves da. Comentários ao art. 21 da LINDB. In: DUQUE, Marcelo Schenk; RAMOS, Rafael (coord.). Segurança jurídica na aplicação do Direito Público. Salvador: JusPodivm, 2019.

DIDIER, Fredie Souza; OLIVEIRA, Rafael Alexandria. Dever judicial de considerar as consequências práticas da decisão: interpretando o art. 20 da Lei de Introdução às Normas do Direito Brasileiro. A \& C - Revista de Direito Administrativo \& Constitucional, Belo 
DINIZ, Cláudio Smirne; MENDES, Rullyan Levi Maganhati. O primado da realidade na lei de introdução às normas do direito brasileiro

Horizonte, ano 19, n. 75, p. 143-160, jan./mar. 2019. DOI:

http://dx.doi.org/10.21056/aec.v20i75.1068. Disponível em:

http://www.revistaaec.com/index.php/revistaaec/article/view/1068. Acesso em: 25 out. 2021.

DINIZ, Cláudio Smirne; DINIZ, Hirmínia Dorigan de Matos. Nova Lei de Introdução às Normas do Direito Brasileiro: definição de parâmetros para o controle da Administração Pública. Revista Jurídica do Ministério Público do Estado do Paraná, Curitiba, ano 5, n. 9, p. 273-298, dez. 2018. Disponível em:

https://escolasuperior.mppr.mp.br/arquivos/File/Biblioteca/Revista_Juridica_do_MPPR/rjmpp ra05e09.pdf. Acesso em: 25 out. 2021.

DUQUE, Marcelo Schenk; RAMOS, Rafael. Comentários ao art. $1^{\circ}$ da Lei 13.655/2018. In: DUQUE, Marcelo Schenk; RAMOS, Rafael (coord.). Segurança jurídica na aplicação do Direito Público. Salvador: JusPodivm, 2019.

FERREIRA, Débora Costa; XIMENES, Julia Maurmann. Diálogos institucionais e impacto orçamentário da judicialização das políticas públicas. Thesis Juris, São Paulo, v. 5, n. 3, p. 808-831, set./dez. 2016. DOI: https://doi.org/10.5585/rtj.v5i3.494. Disponível em: https://periodicos.uninove.br/thesisjuris/article/view/9918/4611. Acesso em: 25 out. 2021.

FREITAS, Juarez. A interpretação sistemática do direito. 4. ed. São Paulo: Malheiros, 2004.

GARCIA, Gustavo Filipe Barbosa. Introdução ao estudo do Direito. 7. ed. Salvador: JusPodivm, 2020.

GRAU, Eros Roberto. O direito posto e o direito pressuposto. 5. ed. São Paulo: Malheiros, 2003.

GUERRA, Sérgio; PALMA, Juliana Bonacorsi de. Art. 26 da LINDB - Novo regime jurídico de negociação com a Administração Pública. Revista de Direito Administrativo, Rio de Janeiro, p. 135-169, nov. 2018. Edição especial. DOI:

https://doi.org/10.12660/rda.v0.2018.77653. Disponível em:

https://bibliotecadigital.fgv.br/ojs/index.php/rda/article/view/77653. Acesso em: 25 out. 2021.

GUIMARÃES, Bernardo Strobel. A LINDB e os pressupostos de controle em uma Administração complexa. In: VALIATI, Thiago Priess; HUNGARO, Luis Alberto; CASTELLA, Gabriel Morettini e. (coord.). A lei de introdução e o direito administrativo brasileiro. Rio de Janeiro: Lumen Juris, 2019.

HAEBERLIN, Mártin. Comentários ao art. 22 da LINDB. In: DUQUE, Marcelo Schenk; RAMOS, Rafael (coord.). Segurança jurídica na aplicação do Direito Público. Salvador: JusPodivm, 2019.

HEINEN, Juliano. Comentários ao art. 28 da LINDB. In: DUQUE, Marcelo Schenk; RAMOS, Rafael (coord.). Segurança jurídica na aplicação do Direito Público. Salvador: JusPodivm, 2019.

JORDÃO, Eduardo. Art. 22 da LINDB - Acabou o romance: reforço do pragmatismo no Direito Público brasileiro. Revista de Direito Administrativo, Rio de Janeiro, p. 63-92, nov. 
DINIZ, Cláudio Smirne; MENDES, Rullyan Levi Maganhati. O primado da realidade na lei de introdução às normas do direito brasileiro

2018. Edição especial. DOI: https://doi.org/10.12660/rda.v0.2018.77650. Disponível em: https://bibliotecadigital.fgv.br/ojs/index.php/rda/article/view/77650. Acesso em: 25 out. 2021.

JUSTEN FILHO, Marçal. Art. 20 da LINDB - Dever de transparência, concretude e proporcionalidade nas decisões públicas. Revista de Direito Administrativo, Rio de Janeiro, p. 13-41, nov. 2018. Edição especial. DOI: https://doi.org/10.12660/rda.v0.2018.77648. Disponível em: https://bibliotecadigital.fgv.br/ojs/index.php/rda/article/view/77648. Acesso em: 25 out. 2021.

LEAL, Fernando. Inclinações pragmáticas no Direito Administrativo: nova agenda, novos problemas. O caso do PL 349/15. In: LEAL, Fernando; MENDONÇA, José Vicente Santos de (org.). Transformações do Direito Administrativo: consequencialismo e estratégias regulatórias. Rio de Janeiro: Escola de Direito do Rio de Janeiro da Fundação Getulio Vargas, 2016. Disponível em: https://bibliotecadigital.fgv.br/dspace/handle/10438/18009. Acesso em: 25 out. 2021.

LEVIN, Alexandre. Consulta e audiência pública: considerações sobre o art. 29 do DecretoLei n. 4.657/1942 (Lei de Introdução às Normas do Direito Brasileiro). In: CUNHA FILHO, Alexandre Jorge Carneiro da; ISSA, Rafael Hamze; SCHWIND, Rafael Wallbach (coord.). Lei de Introdução às Normas do Direito Brasileiro - Anotada. v. II. São Paulo: Quartier Latin, 2018.

MACKAAY, Ejan; ROUSSEAU, Stéphane. Análise econômica do direito. Tradução de Rachel Sztajn. São Paulo: Atlas, 2015.

MAFFINI, Rafael. Comentários ao art. 20 da LINDB. In: DUQUE, Marcelo Schenk; RAMOS, Rafael (coord.). Segurança jurídica na aplicação do Direito Público. Salvador: JusPodivm, 2019a.

MAFFINI, Rafael. Comentários ao art. 24 da LINDB. In: DUQUE, Marcelo Schenk; RAMOS, Rafael (coord.). Segurança jurídica na aplicação do Direito Público. Salvador: JusPodivm, 2019b.

MAFFINI, Rafael; HEINEN, Juliano. Análise acerca da aplicação da Lei de Introdução às Normas do Direito Brasileiro (na redação dada pela Lei n. 13.655/2018) no que concerne à interpretação de normas de direito público: operações interpretativas e princípios gerais de direito administrativo. Revista de Direito Administrativo, Rio de Janeiro, v. 277, n. 3, p. 247-278, set./dez. 2018. DOI: https://doi.org/10.12660/rda.v277.2018.77683. Disponível em: https://bibliotecadigital.fgv.br/ojs/index.php/rda/article/view/77683. Acesso em: 25 out. 2021.

MARQUES JUNIOR, José Jair. A prorrogação e renovação de contratos públicos no contexto da alteração de orientações gerais, à luz do artigo 24 da LINDB. In: CUNHA FILHO, Alexandre Jorge Carneiro da; ISSA, Rafael Hamze; SCHWIND, Rafael Wallbach (coord.). Lei de Introdução às Normas do Direito Brasileiro - Anotada. v. II. São Paulo: Quartier Latin, 2018.

MARQUES NETO, Floriano de Azevedo; MOREIRA, Egon Bockmann. Uma lei para o Estado de Direito contemporâneo. In: PEREIRA, Flávio Henrique Unes (coord.). Segurança jurídica e qualidade das decisões públicas: desafios de uma sociedade democrática. 
DINIZ, Cláudio Smirne; MENDES, Rullyan Levi Maganhati. O primado da realidade na lei de introdução às normas do direito brasileiro

Brasília: Senado Federal, 2015. Disponível em: http://anastasia.com.br/wpcontent/uploads/2015/09/segurancajuridica.pdf. Acesso em: 25 out. 2021.

MARTINS, Ricardo Marcondes. As alterações da LINDB e a ponderação dos atos administrativos. A \& C - Revista de Direito Administrativo \& Constitucional, Belo Horizonte, ano 20, n. 79, p. 259-284, jan./mar. 2020. DOI:

http://dx.doi.org/10.21056/aec.v20i79.1139. Disponível em:

http://www.revistaaec.com/index.php/revistaaec/article/view/1139. Acesso em: 25 out. 2021.

MEDAUAR, Odete. Comentário ao art. 20 da LINDB. In: CUNHA FILHO, Alexandre Jorge Carneiro da; ISSA, Rafael Hamze; SCHWIND, Rafael Wallbach (coord.). Lei de Introdução às Normas do Direito Brasileiro - Anotada. v. II. São Paulo: Quartier Latin, 2018.

MENDONÇA, José Vicente Santos de. Dois futuros (e meio) para o projeto de lei do Carlos Ari. In: LEAL, Fernando; MENDONÇA, José Vicente Santos de (org.). Transformações do Direito Administrativo: consequencialismo e estratégias regulatórias. Rio de Janeiro: Escola de Direito do Rio de Janeiro da Fundação Getulio Vargas, 2016. Disponível em:

https://bibliotecadigital.fgv.br/dspace/handle/10438/18009. Acesso em: 25 out. 2021.

MENDONÇA, José Vicente Santos de. Art. 21 da LINDB - Indicando consequências e regularizando atos e negócios. Revista de Direito Administrativo, Rio de Janeiro, p. 43-61, nov. 2018. Edição especial. DOI: https://doi.org/10.12660/rda.v0.2018.77649. Disponível em: https://bibliotecadigital.fgv.br/ojs/index.php/rda/article/view/77649. Acesso em: 25 out. 2021.

MINISTÉRIO PÚBLICO FEDERAL. Nota Técnica Conjunta n. 1/2018. Disponível em: http://www.mpf.mp.br/atuacao-tematica/ccr5/notastecnicas/docs/Nota\%20Tecnica\%201_2018.pdf. Acesso em: 25 out. 2021.

MONTEIRO, Vera. Art. 29 da LINDB - Regime jurídico da consulta pública. Revista de Direito Administrativo, Rio de Janeiro, p. 225-242, nov. 2018. Edição especial. DOI: https://doi.org/10.12660/rda.v0.2018.77656. Disponível em: https://bibliotecadigital.fgv.br/ojs/index.php/rda/article/view/77656. Acesso em: 25 out. 2021.

MOREIRA, Egon Bockmann; PEREIRA, Paula Pessoa. Art. 30 da LINDB - O dever público de incrementar a segurança jurídica. Revista de Direito Administrativo, Rio de Janeiro, p. 243-274, nov. 2018. Edição especial. DOI: https://doi.org/10.12660/rda.v0.2018.77657. Disponível em: https://bibliotecadigital.fgv.br/ojs/index.php/rda/article/view/77657. Acesso em: 25 out. 2021.

NADER, Paulo. Introdução ao estudo do Direito. 42. ed. Rio de Janeiro: Forense, 2020.

NISHIYAMA, Adolfo Mamoru; PINHEIRO, Flavia de Campos; LAZARI, Rafael de. Manual de hermenêutica constitucional. Belo Horizonte: D’Plácido, 2018.

NOGUEIRA JÚNIOR, Alberto. Comentários à Lei da Segurança Jurídica e Eficiência: Lei n. 13.655, de 25 de abril de 2018. Rio de Janeiro: Lumen Juris, 2019.

NOHARA, Irene Patrícia. LINDB: Lei de Introdução às Normas do Direito Brasileiro, hermenêutica e novos parâmetros ao Direito Público. Curitiba: Juruá, 2018a. 
DINIZ, Cláudio Smirne; MENDES, Rullyan Levi Maganhati. O primado da realidade na lei de introdução às normas do direito brasileiro

NOHARA, Irene Patrícia. Comentário ao art. 22, $\S 1^{\circ}$, da LINDB. In: CUNHA FILHO, Alexandre Jorge Carneiro da; ISSA, Rafael Hamze; SCHWIND, Rafael Wallbach (coord.). Lei de Introdução às Normas do Direito Brasileiro - Anotada. v. II. São Paulo: Quartier Latin, 2018b.

OLIVEIRA, Carlos Eduardo Elias de. A segurança jurídica nos vários ramos do Direito e nos cartórios extrajudiciais: repercussões da LINDB após a Lei n. 13.655/2018. Brasília: Núcleo de Estudos e Pesquisas/CONLEG Senado, junho/2018 (Texto para discussão n. 250). 2018a. Disponível em:

https://www2.senado.leg.br/bdsf/bitstream/handle/id/543379/TD250.pdf?sequence=1\&isAllo wed=y. Acesso em: 25 out. 2021.

OLIVEIRA, Odilon Cavallari de. Alterações à Lei de Introdução às Normas do Direito Brasileiro e controle. In: PINTO, Élida Graziane et al. Política pública e controle: um diálogo interdisciplinar em face da Lei n. 13.655/2018, que alterou a Lei de Introdução às Normas do Direito Brasileiro. Belo Horizonte: Fórum, $2018 \mathrm{~b}$.

PALMA, Juliana Bonacorsi de. Segurança jurídica para a inovação pública: a nova Lei de Introdução às Normas do Direito Brasileiro (Lei n. 13.655/2018). Revista de Direito Administrativo, Rio de Janeiro, p. 209-249, maio/ago. 2020. DOI: https://doi.org/10.12660/rda.v279.2020.82012. Disponível em: https://bibliotecadigital.fgv.br/ojs/index.php/rda/article/view/82012. Acesso em: 25 out. 2021.

PIAZENSKI, Fernando José; AGUIAR, Julio Cesar de. Judicialização da saúde e pragmatismo. Thesis Juris, São Paulo, v. 6, n. 2, p. 365-386, maio/ago. 2017. DOI: https://doi.org/10.5585/rtj.v6i2.598. Disponível em:

https://periodicos.uninove.br/thesisjuris/article/view/9008. Acesso em: 25 out. 2021.

RODRIGUES, Itiberê de Oliveira Castellano. Comentários ao art. 29 da LINDB. In: DUQUE, Marcelo Schenk; RAMOS, Rafael (coord.). Segurança jurídica na aplicação do Direito Público. Salvador: JusPodivm, 2019.

SARMENTO, Daniel. Por um constitucionalismo inclusivo: história constitucional brasileira, teoria da Constituição e direitos fundamentais. Rio de Janeiro: Lumen Juris, 2010.

SILVA, Almiro do Couto e. Conceitos fundamentais do Direito no Estado constitucional. São Paulo: Malheiros, 2015.

SILVEIRA, Marilda de Paula; SILVA, Marco Aurélio de Barcelos. Revogação do ato administrativo e aplicação do regime de transição: comentários ao art. 23 da Lei n. 13.655/2018. In: CUNHA FILHO, Alexandre Jorge Carneiro da; ISSA, Rafael Hamze; SCHWIND, Rafael Wallbach (coord.). Lei de Introdução às Normas do Direito Brasileiro - Anotada. v. II. São Paulo: Quartier Latin, 2018.

SOUZA, Rodrigo Pagani de; ALENCAR, Letícia Lins de. O dever de contextualização na interpretação e aplicação do Direito Público. In: VALIATI, Thiago Priess; HUNGARO, Luis Alberto; CASTELLA, Gabriel Morettini e (coord.). A Lei de Introdução e o Direito Administrativo brasileiro. Rio de Janeiro: Lumen Juris, 2019. 
DINIZ, Cláudio Smirne; MENDES, Rullyan Levi Maganhati. O primado da realidade na lei de introdução às normas do direito brasileiro

SUNDFELD, Carlos Ari. Direito Administrativo para céticos. $2^{\mathrm{a}}$ ed. São Paulo: Malheiros, 2017.

SUNDFELD, Carlos Ari. Prefácio. In: DUQUE, Marcelo Schenk; RAMOS, Rafael (coord.). Segurança jurídica na aplicação do Direito Público. Salvador: JusPodivm, 2019.

SUNDFELD, Carlos Ari; MARQUES NETO, Floriano de Azevedo. Uma nova lei para aumentar a qualidade jurídica das decisões públicas e seu controle. In: SUNDFELD, Carlos Ari (coord.). Contratações públicas e seu controle. São Paulo: Malheiros, 2013.

SUNDFELD, Carlos Ari; VORONOFF, Alice. Art. 27 da LINDB - Quem paga pelos riscos dos processos? Revista de Direito Administrativo, Rio de Janeiro, p. 171-201, nov. 2018. Edição especial. DOI: https://doi.org/10.12660/rda.v0.2018.77654. Disponível em: https://bibliotecadigital.fgv.br/ojs/index.php/rda/article/view/77654. Acesso em: 25 out. 2021.

VITORELLI, Edilson. A Lei de Introdução às Normas do Direito Brasileiro e a ampliação dos parâmetros de controle dos atos administrativos discricionários: o Direito na era do consequencialismo. Revista de Direito Administrativo, Rio de Janeiro, p. 79-112, maio/ago. 2020. DOI: https://doi.org/10.12660/rda.v279.2020.82006. Disponível em: https://bibliotecadigital.fgv.br/ojs/index.php/rda/article/view/82006. Acesso em: 25 out. 2021. 